\title{
LCP1 Antibody
}

National Cancer Institute

\section{Source}

National Cancer Institute. LCP1 Antibody. NCI Thesaurus. Code C122774.

Any immunog lobulin that recognizes L-plastin protein. 